\title{
Dysregulation of serum miR-1204 and its potential as a biomarker for the diagnosis and prognosis of breast cancer
}

\author{
Suli Han' \\ Peng $L i^{1}$ \\ Donghong Wang \\ (iD) Hui Yan
}

1. Department of Clinical Laboratory, the Affiliated Heping Hospital of Changzhi Medical College, Changzhi, Shanxi, 046000 , China.

http://dx.doi.org/10.1590/1806-9282.66.6.732

\section{SUMMARY}

OBJECTIVE: A previous study has reported that miR-1204 exerted oncogenic effects in breast cancer (BC). The purpose of our paper was to evaluate the expressions of tissue and serum miR-1204 in patients with BC and further investigate its biomarker potential.

METHODS: The expressions of tissue and serum miR-1204 were investigated by qRT-PCR in 144 BC patients and 38 healthy controls. Chi-square tests were conducted to examine the associations between miR-1204 expressions and clinicopathological factors. Then, the associations of miR-1204s level with the survival of BC patients were determined by performing the Kaplan-Meier and multivariate analysis. The receiver operating characteristics (ROC) and area under the OC curve (AUC) were obtained to validate the diagnostic values of miR-1204.

RESULTS: We found that the expressions of miR-1204 were increased in both tissue and serum samples from BC patients. Multivariate assays identified tissue and serum miR-1204 overexpression as an independent poor prognostic factor. In addition, ROC curve assays indicated that tissue and serum miR-1204 are potential diagnostic markers of BC.

CONCLUSIONS: Detection of tissue and serum miR-1204 levels could have clinical potential as a novel prognostic/diagnostic biomarker for BC patients.

KEYWORDS: MicroRNAs. Breast neoplasms/diagnosis. Prognosis, Biomarkers. Serum.

\section{INTRODUCTION}

Breast cancer (BC) is one of the frequently diagnosed malignant tumors and the second leading cause of neoplasm mortality for women. Moreover, its incident rate has increased in recent years ${ }^{1}$. BC is a complex disease, which involves multiple risk factors $^{2}$. During recent decades, remarkable advancement has been made, and this malignancy can now be treated by surgery, endocrine, cytotoxic, or targeted therapies ${ }^{3}$. However, the overall prognosis of $\mathrm{BC}$ is not satisfactory.

MicroRNAs (miRNAs) are highly conserved, single-stranded, and non-coding RNAs whose lengths are approximately twenty-two nucleotides (nt) and that are involved in the post-transcriptional modulation of genes expression ${ }^{4}$. MiR-1204 is a recently identified miRNA that has also been shown to be upregulated in 
several types of human malignancy, and its dysregulations played an essential role in tumor progression by affecting the tumor cellular function ${ }^{5}$. Recently, Liu et al. ${ }^{6}$ firstly reported that miR-1204 was highly expressed in BC and served as a tumor promoter in vitro. However, the clinical importance of miR-1204 in $\mathrm{BC}$ remained largely unclear.

In this study, we aimed to investigate the possibility that miR-1204 could serve as a diagnostic and prognostic biomarker in BC.

\section{METHODS}

\section{Patients and Tissue Samples}

Serum samples and BC samples were obtained from patients who underwent radical mastectomy or modified radical mastectomy at the Jilin Cancer Hospital from 2010 to 2013. Meanwhile, 38 healthy individuals' sera were included as normal controls. All the patients with BC were diagnosed by two skilled pathologists. All patients had not received radiotherapy or chemotherapy prior to mastectomy. Tumors were staged based on the Seventh Edition of the Cancer Staging Manual. The clinicopathological information, collected from medical records. Prior to enrollment, written informed consent was obtained from every contributor. The study was approved by the Ethical Committee of the Jilin Cancer Hospital.

\section{Quantitative real-time RT-PCR}

Total RNA was extracted from $500 \mu \mathrm{L}$ of blood samples using a miRVana PARIS Kit (Ambion, Kunmin, Yunnan, China) and washed out into $150 \mu \mathrm{L}$ of pre-heated Elution Solution. Total RNA was extracted from all tissues from every contribution with TRIzol reagent (Invitrogen, Carlsbad, CA, USA). Complementary DNA (cDNA) was synthesized with the PrimeScript II First Strand cDNA Synthesis kit (TaKaRa, Otsu, Shiga, Japan). RT-PCR was then conducted via miRNA-specific TaqMan MiRNA Assay Kit (ABI, Xuhui, Shanghai, China) on the useful Biosystems 7500 (ThermoFisher Scientific, Waltham, MA, USA). The levels of miRNA were determined based on the threshold cycle $(\mathrm{Ct})$, and relative expressions were estimated employing the $2^{-\Delta \Delta C t}$ methods, using the expression level of the glyceraldehyde phosphate dehydrogenase (GAPDH) as a reference gene. The following primers were used: miR-1204 sense primer 5'- GGCTCGTGGCCTGGTCTC-3' and antisense primer 5'- CTCAACTGGTGTCGTGGA -3' and GAPDH sense primer 5'-GCTGGCGCTGAGTACGTCGT-3' and antisense primer 5'-ACG TTGGCAGTGGGGACACG-3'.

\section{Statistical analysis}

Statistical analyses were performed using the SPSS 16.0 software (SPSS Inc., Chicago, IL, USA). The possible significances of differences between groups were assessed by the Student's $t$-test, Wilcoxon test, or Chi-square test. The cumulative survival probabilities were measured using the Kaplan-Meier method, and differences were determined by the use of the logrank tests. Hazard ratios were determined by the Cox regression model. ROC curve assays were performed to complete the diagnostic performances of miR-1204 expressions by originally identifying patients with BC from the healthy controls. A $p$ value $<0.05$ was considered statistically significant.

\section{RESULTS}

The miR-1204 expression was upregulated in the tissue and serum of $B C$ patients

In order to explore the role of miR-1204 in BC, we performed RT-PCR to study whether miR-1204 was abnormally expressed in BC tissues and serum. As presented in Figure 1A, we found that miR-1204 expressions were significantly up-regulated in BC tissues compared to matched normal breast tissues $(p<0.01)$. In addition, we also observed that serum miR1204 levels were obviously higher in BC patients compared with normal controls with $p<0.01$ (Figure 1B). Then, we wondered whether the expressions of tissue miR-1204 were associated with the levels of serum miR-1204. As shown in Figure 1C, Spearman order correlations assays were performed, and linear correlations between the miR-1204 expressions in the BC tissues and the serum ones were validated $(p<0.001)$.

\section{Associations between miR-1204 expressions} and the clinicopathological features of $B C$

For a superior understanding of the clinical significance of miR-1204 expressions in BC, our group used the median levels of miR-1204 in tissues and serum of BC for the division of all 144 BC patients into a high-expression group and a low-expression group. As shown in Table 1, we found that high miR1204 levels distinctly correlated with differentiation grade $(p=0.008)$, advanced TNM stage $(p=0.013)$, and lymph nodes metastasis $(p=0.002)$. Moreover, similar results were also observed in serum samples. 
However, no distinct alteration was found between miR-1204 expressions and patients' age, tumor size, ER, PR, HER-2 $(p>0.05)$.

TABLE 1. CORRELATION BETWEEN MIR-1204 EXPRESSION AND CLINICOPATHOLOGICAL CHARACTERISTICS IN BC PATIENTS.

\begin{tabular}{|c|c|c|c|c|c|c|c|}
\hline \multirow[t]{2}{*}{ Factors } & \multirow[t]{2}{*}{$\begin{array}{l}\text { Num- } \\
\text { ber }\end{array}$} & \multicolumn{3}{|c|}{$\begin{array}{l}\text { Tissue miR-1204 } \\
\text { level }\end{array}$} & \multicolumn{3}{|c|}{$\begin{array}{l}\text { Serum miR-1204 } \\
\text { level }\end{array}$} \\
\hline & & Low & High & $\mathrm{p}$ & Low & High & $p$ \\
\hline Age (years) & & & & NS & & & NS \\
\hline$<40$ & 65 & 30 & 35 & & 28 & 37 & \\
\hline$\geq 40$ & 79 & 44 & 35 & & 41 & 38 & \\
\hline $\begin{array}{l}\text { Tumor size } \\
(\mathrm{cm})\end{array}$ & & & & NS & & & NS \\
\hline$<2.5$ & 94 & 53 & 41 & & 48 & 46 & \\
\hline$\geq 2.5$ & 50 & 21 & 29 & & 21 & 29 & \\
\hline ER & & & & NS & & & NS \\
\hline Positive & 62 & 28 & 34 & & 31 & 31 & \\
\hline Negative & 82 & 46 & 36 & & 38 & 44 & \\
\hline PR & & & & NS & & & NS \\
\hline Positive & 56 & 25 & 31 & & 31 & 25 & \\
\hline Negative & 88 & 49 & 39 & & 38 & 50 & \\
\hline HER-2 & & & & NS & & & NS \\
\hline Positive & 65 & 29 & 36 & & 33 & 32 & \\
\hline Negative & 79 & 45 & 34 & & 36 & 43 & \\
\hline $\begin{array}{l}\text { Differentia- } \\
\text { tion grade }\end{array}$ & & & & 0.003 & & & 0.008 \\
\hline G1/G2 & 86 & 53 & 33 & & 49 & 37 & \\
\hline G3 & 58 & 21 & 37 & & 20 & 38 & \\
\hline TNM stage & & & & 0.002 & & & 0.013 \\
\hline $1 / I 1$ & 96 & 58 & 38 & & 53 & 43 & \\
\hline III & 48 & 16 & 32 & & 16 & 32 & \\
\hline $\begin{array}{l}\text { Lymph nodes } \\
\text { metastasis }\end{array}$ & & & & 0.003 & & & 0.002 \\
\hline No & 99 & 59 & 40 & & 56 & 43 & \\
\hline Yes & 45 & 15 & 30 & & 13 & 32 & \\
\hline
\end{tabular}

Prognostic value of tissue and serum miR1204 in BC

In order to scrutinize the associations between miR-1204 expressions and clinical overall survival, our group reexamined the detailed clinical data of 144 BC patients and performed Kaplan-Meier analysis. As shown in Figure 2A, we found that patients with high tissue miR-1204 expressions lived shorter than those with low tissue miR-1204 expressions ( $p=0.0082)$. Similar results were also observed in patients with high serum miR-1204 expression ( $p=0.006$, Figure 2B). Furthermore, we also found that patients with high tissue and serum miR-1204 expression levels tended to have shorter disease-free survival times (both $p<0.05$, Figure 2C, and 2D). In addition, univariate analysis showed that differentiation grade, TNM stage and lymph nodes metastasis, tissue miR-1204 expression, and serum miR-1204 expressions were powerfully correlated with worse overall survival ( $p$ $<0.05$,). Further multivariate assays confirmed that high tissue miR-1204 expression level ( $\mathrm{HR}=3.895$, 95\% CI: $1.213-6.014 ; p=0.001)$ and high serum miR-1204 expression (HR=3.243, 95\% CI: 1.178-4.468; $p=0.009$ ) were independent prognostic biomarkers for suggesting unfavorable overall survival in BC patients.

Diagnostic value of tissue and serum miR1204 marker

As shown in Figure 3A, the AUC of 0.854 was obtained according to ROC assay. Furthermore, the specificity was $82.3 \%$ and the sensitivity was $94.8 \%$ with an optimal cut-off value of 4.82 . Moreover, we evaluated the diagnostic capabilities of serum miR1204 for BC; the result of ROC indicated a optimal

FIGURE 1. MIR-12O4 EXPRESSION IS UPREGULATED IN BOTH BC TISSUES AND PATIENTS' SERA BY RT-PCR. (A) THE EXPRESSION LEVELS OF MIR-1204 IN BC TISSUES WERE SIGNIFICANTLY HIGHER THAN THOSE IN NONCANCEROUS BREAST TISSUES (P < 0.01). (B) THE SERUM LEVELS OF MIR-1204 WERE ALSO MARKEDLY UPREGULATED IN PATIENTS WITH BC COMPARED WITH HEALTHY CONTROLS $(P<0.01)$. (C) INVERSE CORRELATION BETWEEN TISSUES MIR-1204 AND SERUM MIR-1204 EXPRESSION USING PEARSON'S CORRELATION COEFFICIENT.

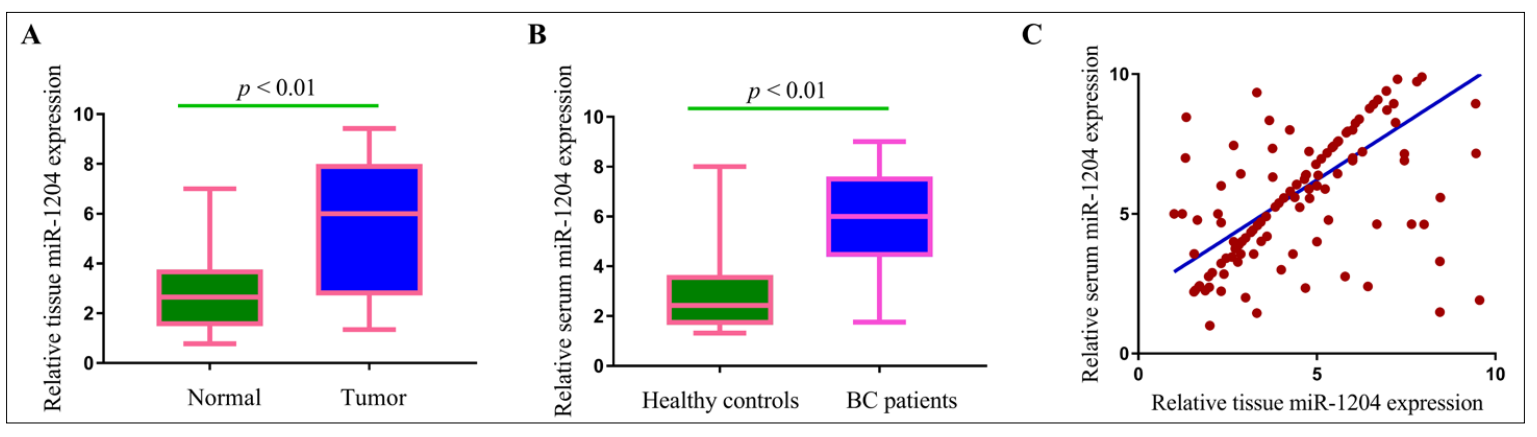


FIGURE 2. KAPLAN-MEIER CURVES FOR OVERALL SURVIVAL AND DISEASE-FREE SURVIVAL OF 144 BC PATIENTS, DIVIDED ACCORDING TO MIR-1204 EXPRESSION LEVELS. (A, B) HIGH TISSUE AND SERUM MIR-1204 EXPRESSION WAS SIGNIFICANTLY ASSOCIATED WITH POOR OVERALL SURVIVAL (BOTH P < 0.05). (C, D) HIGH TISSUE AND SERUM MIR-1204 EXPRESSION WAS SIGNIFICANTLY ASSOCIATED WITH POOR DISEASE-FREE SURVIVAL (BOTH P< 0.05).
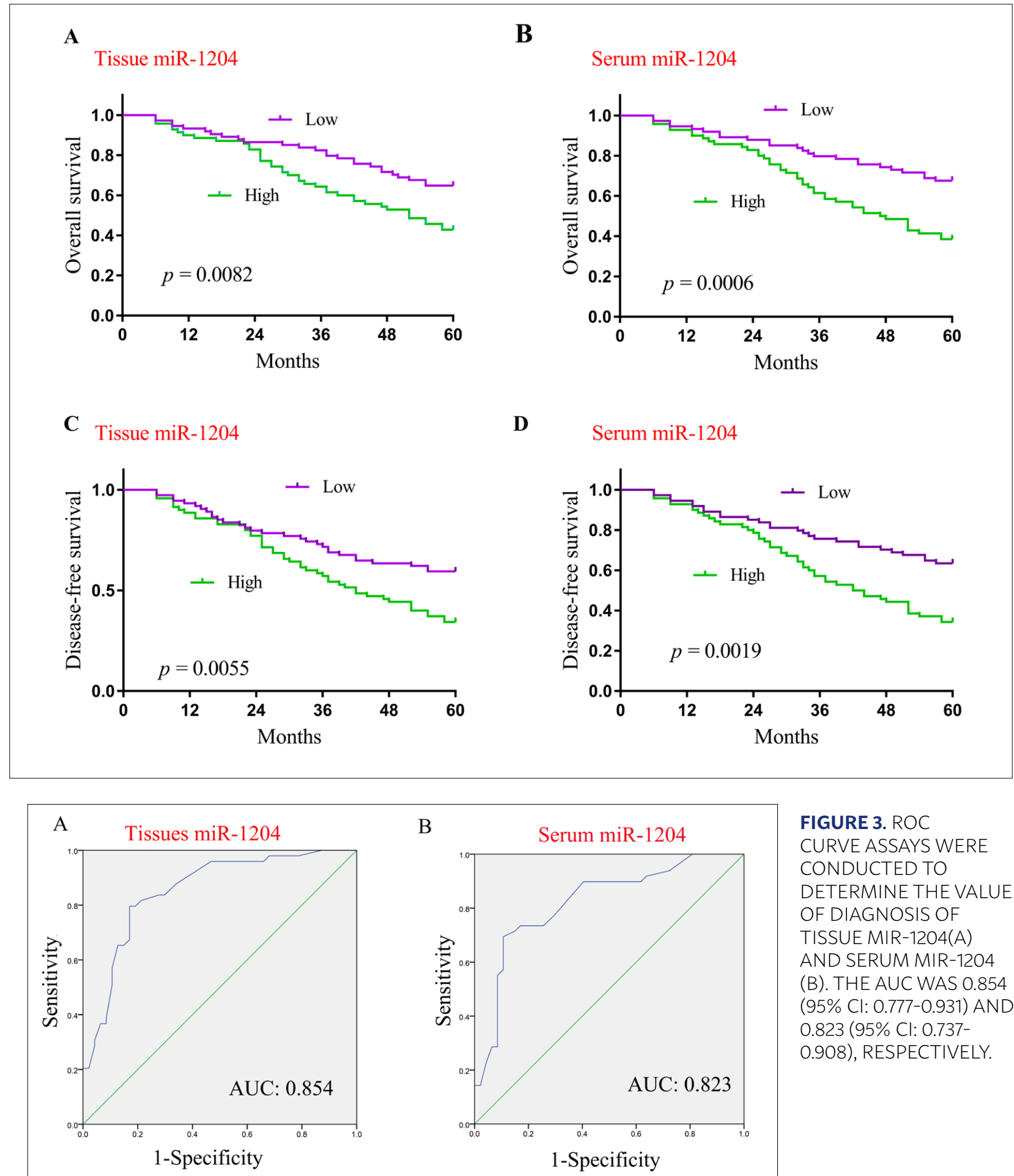

FIGURE 3. ROC

CURVE ASSAYS WERE

CONDUCTED TO

DETERMINE THE VALUE OF DIAGNOSIS OF

TISSUE MIR-1204(A)

AND SERUM MIR-1204

(B). THE AUC WAS 0.854

(95\% Cl: 0.777-0.931) AND

0.823 (95\% Cl: 0.737-

0.908), RESPECTIVELY.

\section{DISCUSSION}

cutoff value of 4.77 for serum miR-1204 levels, with sensitivity at $79.6 .1 \%$ and specificity at $92.5 \%$, with an AUC of 0.823 in differentiating BC patients from healthy controls (Figure 3B).
In this study, in line with the previous one, our group also revealed, using RT-PCR, that tissue miR1204 expressions were up-regulated in BC tissues. Those results revealed that the dysregulation of 
miR-1204 may be involved in the progression of BC. Recently, emerging studies have highlighted the novel application of miRNAs as potential biomarkers for the detection of $\mathrm{BC}^{7-9}$. Our findings provided evidence that miR-1204 could be a candidate.

In this study, we analyzed the association between tissue and serum miR-1204 and clinicopathological characteristics in BC patients, finding that high miR1204 expression was associated with TNM stage, differentiation grade, and lymph nodes metastasis. In addition, the result of the Kaplan-Meier survival was that BC patients with higher tissue and serum miR-1204 expression had shorter overall survival and disease-free survival time. More importantly, multivariate analysis indicated that tissue and serum miR-1204 expression was an independent prognostic factor for poor OS and DFS rates of BC patients.

In this study, ROC curve assays revealed that specimens of miR-1204 were useful markers for discriminating $\mathrm{BC}$ tissues from matched normal breast tissues, with an AUC of 0.854. Moreover, our results also confirmed that serum miR-1204 could be served as a hopeful noninvasive marker in early detections of BC. To the best of our knowledge, our current research is the first to provide important evidence showing the potential role of serum miR-1204 in the screening of BC.

\section{CONCLUSIONS}

This study indicated that tissue and serum miR1204 might potentially serve as a novel biomarker for BC patients.

\section{Conflict of Interest}

The authors declare that they have no conflict of interests.

\section{Author Contributions}

All authors contributed to data analysis, drafting and revising the article, gave final approval of the version to be published, and agree to be accountable for all aspects of the work.

\section{RESUMO}

OBJETIVO: Um estudo anterior indicou que o miR-1204 exerce efeitos oncogênicos no Câncer de Mama (CM). O objetivo deste trabalho foi avaliar as expressões de miR-1204 sérico e em tecidos em pacientes com CM e investigar o seu potencial biomarcador.

METOdologiA: As expressões de miR-1204 sérico e em tecidos foram investigadas por qRT-PCR em 144 pacientes com CM e 38 controles saudáveis. Testes qui-quadrados foram realizados para examinar as associações entre as expressões de miR-1204 e os fatores clinicopatológicos. Em seguida, as associações entre nível de miR-1204s e sobrevida de pacientes de CM foram determinadas através de análises de Kaplan-Meier e multivariadas. A Curva Característica de Operação do Receptor (ROC) e área sob a curva (AUC) foram obtidas para validar o valor diagnóstico do MIR-1204.

RESULTADOS: Descobrimos que as expressões do MIR-1204 estavam aumentadas em amostras de tecido e séricas de pacientes com CM. Análises multivariadas identificaram a superexpressão de miR-1204 sérico e em tecidos como um fator independente de prognóstico ruim. Além disso, as curvas ROC indicaram que o miR-1204 sérico e em tecidos é um possível marcador de diagnóstico de CM.

CONCLUSÃO: A detecção dos níveis MIR-1204 em tecidos e séricos pode ter potencial clínico como um novo biomarcador de prognóstico/ diagnóstico para pacientes de CM.

PALAVRAS-CHAVE: MicroRNAs. Neoplasias/diagnóstico da mama. Prognóstico. Biomarcadores. Soro.

\section{REFERENCES}

1. Miller KD, Siegel RL, Lin CC, Mariotto AB, Kramer IL, Rowland JH, et al. Cancer treatment and survivorship statistics, 2016. CA Cancer J Clin. 2016;66(4):271-89

2. Majeed W, Aslam B, Javed I, Khaliq T, Muhammad F, Ali A, et al. Breast cancer: major risk factors and recent developments in treatment. Asian Pac J Cancer Prev. 2014;15(8):3353-8.

3. Uchida K, Ohashi H, Kinoshita S, Nogi H, Kato K, Toriumi Y, et al. Breast cancer screening and the changing population pyramid of Japan. Breast Cancer. 2015;22(2):172-6.

4. Baigude $H$, Rana TM. Strategies to antagonize miRNA functions in vitro and in vivo. Nanomedicine (Lond). 2014;9(16):2545-55.

5. Bisio A, De Sanctis V, Del Vescovo V, Denti MA, Jegga AG, Inga A, et al. Identification of new $p 53$ target microRNAs by bioinformatics and functional analysis. BMC Cancer. 2013;13:552.
6. Liu X, Bi L, Wang $\mathrm{O}$, Wen M, Li C, Ren Y, et al. miR-1204 targets VDR to promotes epithelial-mesenchymal transition and metastasis in breast cancer. Oncogene. 2018;37(25):3426-39.

7. Wang F, Hou J, Jin W, Li J, Yue Y, Jin H, et al. Increased circulating microRNA-155 as a potential biomarker for breast cancer screening: a meta-analysis. Molecules. 2014;19(5):6282-93.

8. Chen D, Dang BL, Huang IZ, Chen M, Wu D, Xu ML, et al. MiR-373 drives the epithelial-to-mesenchymal transition and metastasis via the miR373-TXNIP-HIF1 $\alpha$-TWIST signaling axis in breast cancer. Oncotarget. 2015;6(32):32701-12.

9. Ng EK, Li R, Shin VY, Jin HC, Leung CP, Ma ES, et al. Circulating microRNAs as specific biomarkers for breast cancer detection. PLoS One. 2013;8(1):e53141. 